\title{
The impact of security and regional integration on poverty reduction in Afghanistan
}

\author{
Farid Ahmad Farzam Rahimi \\ Ritsumeikan Asia Pacific University (APU) \\ Japan \\ farzam_rahimi2000@yahoo.com
}

\begin{abstract}
Afghanistan has 6 neighbors: Tajikistan, Turkmenistan, and Uzbekistan (to the north), Iran (to the West), Pakistan (to the South-East), and China (to the remote East). Intervention and continuous war as well as insecurity are the main thematic areas of poverty in Afghanistan. Moreover, in many cases, poverty in Afghanistan is mainly affected by economic and political policies of neighboring countries. Therefore, lack of economic and political integration at the regional level has increased the poverty in Afghanistan. By any measure such as per capita income, life expectancy, health, education, welfare, or freedom, Afghanistan is a very poor country. This paper discusses poverty and the dimensions of poverty in Afghanistan. In addition, this paper presents ways to reduce poverty through providing security and regional integration with neighboring countries.
\end{abstract}

Received: January, 2015 1st Revision: March, 2015 Accepted: April, 2015

DOI:

Keywords: Poverty, Poverty Reduction, Security, Regional Integration

JEL Code: H56, I32, R13

\section{INTRODUCTION}

"The concepts of poverty have developed rapidly over the last thirty years, and international attention is now focused more sharply on poverty reduction than it was twenty years ago (Agola \& Awange, 2014, p. 41)". Poverty is a big challenge all around the world, especially, in non-developed and developing countries. Poverty is not just about money and it is not easy to define it because poverty affects different people in different ways. For example, in many communities it is about access to basic needs such as food, health, and education.

Moreover, poverty differs from country to country, region to region, and community to community. In order to better illustrate the issue of poverty, this paper addresses the situation of poverty in Afghanistan. It is noteworthy that three decades of continued war in Afghanistan has caused widespread poverty in the country. All the country's infrastructure destroyed by war has caused poverty in the country. Poverty has spread to such an extent that people do not have access to even basic needs.

War has caused insecurity in the country and has been detrimental to the reduction of poverty. Moreover, almost 6 million Afghans fled the country and immigrated to other countries, and about one million 
Afghans were displaced within the country. In addition, in some areas both the public and private assets were looted, expanding poverty day by day in Afghanistan. Therefore, the purpose of this research paper is to describe the key indicators of poverty in Afghanistan. This paper addresses the questions of "Why poverty in Afghanistan?" and "How can poverty be reduced in Afghanistan?"

\section{OVERALL POVERTY IN AFGHANISTAN}

Why poverty in Afghanistan? "More than two decades of conflict, interspersed with a number of serious earthquakes, and culminating in a severe nationwide drought in 1999 - 2001, had dramatic impacts on the Afghan population and particularly its poorest segments (World Bank, 2005, p. 16)”. Approximately 9 million Afghans are not able to meet their basic needs. On average, the poor are only able to consume at a level equal to 78 percent of the estimated cost of basic needs. While 36 percent of the population cannot meet basic consumption needs, there are many more people who are highly susceptible to becoming poor (Ministry of Economic MoE, 2010). Poverty in Afghanistan exists in accordance with different dimensions such as low income, unemployment, illiteracy, disabilities, lack of basic public services, and security problem.

Table 1 describes that the high percent of poverty at the national level is mainly related to people who are living in remote areas including rural and $\mathrm{Kuchi}^{l}$. It is estimated that about 80 percent of the population lives in remote areas. Therefore, the poverty in the remote areas is close to the national average. As a result, the poverty rate among the Kuchi population is very high (54 percent), as well as in rural areas (36 percent). In urban areas, compared to the rural and Kuchi areas, the poverty rate is lower ( 29 percent). The analysis of the survey of National Risk and Vulnerability Assessment NRVA 2011-12 indicates that "poverty has not changed over time, with about 36 percent of the population still consuming below the poverty line. Poverty remains higher in rural areas and amongst the Kuchi population (CSO, 2014, p. 50)".

Table 1

Poverty in Afghanistan

\begin{tabular}{|c|c|c|c|}
\hline Poverty by residence & Poverty rate (\%) & Poverty by region & Poverty rate (\%) \\
\hline \multirow{3}{*}{ Urban } & \multirow{3}{*}{29} & Central & 30.1 \\
\cline { 3 - 4 } & & South & 43.7 \\
\cline { 3 - 4 } & & East & 45.0 \\
\hline \multirow{3}{*}{ Rural } & \multirow{3}{*}{36} & Northeast & 36.8 \\
\cline { 3 - 4 } & & North & 39.5 \\
\cline { 3 - 4 } & & West & 35.4 \\
\hline \multirow{2}{*}{ Kuchi } & \multirow{3}{*}{54} & Southwest & 22.7 \\
\cline { 3 - 4 } & & West Central & 44.9 \\
\cline { 3 - 4 } & & National & $\mathbf{3 6}$ \\
\hline
\end{tabular}

Source: Data Adapted from (MoE, 2010).

Furthermore, poverty in Afghanistan varies in terms of the regions across the country. Table 1 demonstrates the poverty situation according to the NRVA 2007/08. Poverty rate is lower in the Central and South Western regions, but higher in the West Central region because of its climate and remoteness.

1 Kuchi means migration and refers to a specific tribe in Afghanistan. 


\section{METHODS}

In the past 10 years, the Government of Afghanistan has conducted two important national surveys covering key issues across the country. Therefore, this research paper is a descriptive study and discussion of secondary data. The research paper is mainly based on information of National Risk and Vulnerability Assessment of Afghanistan (NRVA 2007/08), NRVA 2011/12, Central Statistic Organization (CSO 2014), and poverty status in 2010 based on a report of the Ministry of Economy of Afghanistan. Poverty in Afghanistan is a big challenge for the government and all communities across the country. The key dimensions of poverty in Afghanistan have been described, of which the prolonged insecurity and conflict are the main issues.

Relevant data has been analyzed using both qualitative and quantitative methods. Quantitative data is described based on descriptive statistics and some charts, tables, and figures are drawn for better description. It is notable that the data of this research paper is up to date and shows the reality on the ground.

\section{FINDINGS}

\subsection{Key Indicators of Poverty in Afghanistan}

There are many indicators of overall poverty in Afghanistan. Widespread poverty that has always plagued the people of Afghanistan is a product of several factors over the years that will require comprehensive assessment and research. Poverty in society is dependent on several factors, but those mainly related to the problems of poverty in Afghanistan can be seen as follows:

\subsubsection{War and Insecurity}

One of the most important indicators of poverty in Afghanistan is the war, and lack of security or poor security. Three decades of war across the country destroyed all infrastructures and displaced hundreds of thousands of people and disrupted their routine living in the country.

Without security, people cannot have a safe life and their facilities cannot be used reasonably. The absence of proper security damages the economic services and keeps it from the market, while instability and insecurity stop technology and industry activities, and cause deterioration of property and facilities. In a society which is not secured enough, looters and illegal powerful groups break the law and violate the rights of the people.

\subsubsection{Low Standard of Living}

Another most important indicator of poverty is the low standard of living of the population, which consists of feeding, clothing, housing and life comforts. Adequate food as one of the basic necessities of life is considered a major factor for health, physical ability, and intellectual growth. Clothing is also another need of people to be achieved in terms of wants, desires, and seasons of the year. Housing is also one of the basic necessities in order to spend the night and have rest.

Poverty is when people do not have a good standard of living. A poor standard of living may include not having access to clean drinking water, a house that is in a bad condition or, not being able to make enough money. Poverty may also mean that people are in poor health and cannot afford to see a doctor or buy medicine (Purves, 2008, p. 5). The housing conditions of the Afghan population can be defined as poor, 
with large differences between urban and rural communities (CSO, 2014, p. 95). Therefore, lack of foods, clothing, and housing mean a low standard of living.

\subsubsection{Education}

Illiteracy, low level of literacy, lack of higher education, and lack of knowledge of the people across the country are also considered as one of the indicators of poverty. A low level of education is an important factor which presents management deficiencies, improper use of funds, non-normative and policy making for growth and development. The head of the household is mostly responsible for household livelihood and his attribute is the strongest determinants of poverty. As shown in table 2, the head's literacy status (27.6\%) is less than the illiteracy rate $(41.6 \%)$. In addition, the illiteracy rate for the poor population is high, therefore, higher illiteracy rate here means higher poverty rate.

Table 2

Household Head Characteristics (\%)

\begin{tabular}{|l|c|c|c|c|}
\hline Household Head Characteristics & Male & Female & Literate & Illiterate \\
\hline Poverty Headcount & 36.4 & 54.7 & 27.6 & 41.6 \\
\hline Share of Poor Population & 99.3 & 0.7 & 27.7 & 72.3 \\
\hline Share of Total Population & 99.6 & 0.5 & 36.6 & 63.5 \\
\hline
\end{tabular}

Source: Data Adapted from CSO, 2014

The existence of about 60 percent illiterate people of which a majority lives in rural areas can play an important role in the spread of the poverty. Now, about six million children are deprived of going to school and more than one million two hundred thousand children panhandle and are involved hard work. Education is closely related to the level of poverty in Afghanistan. Surely the education creates better jobs for the family members in order to earn money. The NRVA 2007/08 reveals that: "Both the literacy and education levels of the household heads tend to correlate with lower level of poverty. The poverty rate falls steadily as the head becomes more educated." (MoE, 2010).

Table 3

Net attendance rate by residence, education level, and sex (\%)

\begin{tabular}{|c|c|c|c|c|c|}
\hline \multirow{2}{*}{$\begin{array}{c}\text { Education } \\
\text { Level }\end{array}$} & \multirow{2}{*}{ Sex } & \multicolumn{3}{|c|}{ Residence } & \multirow{2}{*}{ National } \\
\hline & & Urban & Rural & Kuchi & \\
\hline 1 & 2 & 3 & 4 & 5 & 6 \\
\hline \multirow{3}{*}{ Primary } & Male & 81.8 & 62.7 & 24.5 & 64.4 \\
\hline & Female & 73.6 & 43.8 & 13.4 & 48.3 \\
\hline & Both sexes & 77.9 & 53.8 & 19.4 & 56.8 \\
\hline \multirow{3}{*}{ Secondary } & Male & 62.0 & 37.0 & 7.1 & 42.0 \\
\hline & Female & 47.0 & 15.1 & 0.7 & 23.2 \\
\hline & Both sexes & 54.3 & 26.3 & 4.1 & 32.7 \\
\hline
\end{tabular}




\begin{tabular}{|c|l|c|c|c|c|}
\hline \multicolumn{1}{|c|}{2} & 3 & 4 & 5 & 6 \\
\hline \multirow{4}{*}{ Tertiary } & Male & 16.8 & 4.4 & 0.2 & 8.1 \\
\cline { 2 - 6 } & Female & 8.9 & 0.5 & 0.0 & 2.7 \\
\cline { 2 - 6 } & Both boxes & 13.1 & 2.4 & 0.1 & 5.4 \\
\hline
\end{tabular}

Source: Data Adapted from CSO, 2014.

Table 4 shows that $77.1 \%$ of the adult population (25 years or over) in Afghanistan have no formal education. For men this is around $64.5 \%$ and for women $90.3 \%$. It seems that only one-third of men could further their education, but it was possible only for one-tenth of women. Overall, around $12 \%$ of the adult population in Afghanistan have more than a primary school education (excluding Islamic schooling), which is corresponds to $19 \%$ of the men and $4 \%$ of the women.

Table 4

Population 25 years over, by sex, and by educational attainment (\%)

\begin{tabular}{|l|c|c|c|}
\hline \multicolumn{1}{|c|}{ Educational attainment } & Male & Female & Total \\
\hline No Education & 64.5 & 90.3 & 77.1 \\
\hline Incomplete Primary Education & 4.2 & 1.3 & 2.8 \\
\hline Completed Primary Education & 9.7 & 2.7 & 6.3 \\
\hline Completed Lower Secondary Education & 5.0 & 0.9 & 3.0 \\
\hline Completed Upper Secondary Education & 9.6 & 1.7 & 5.7 \\
\hline Completed Teacher/Technical College & 2.1 & 0.7 & 1.4 \\
\hline Completed University/Post Graduate & 2.6 & 0.5 & 1.6 \\
\hline Completed Islamic School & 2.4 & 1.8 & 2.1 \\
\hline Total & 100.0 & 100.0 & 100.0 \\
\hline
\end{tabular}

Source: Data Adapted from CSO, 2014

\subsubsection{Unemployment}

Unemployment is also considered one of the main causes of poverty in the country, especially in rural Afghanistan. The unemployment rate in Afghanistan is estimated to be $40 \%$. Thus, the high unemployment rate and low salary are other challenges in Afghanistan which raised the poverty rate all around the country. The existence of more than 4 million unemployed young people can be considered to represent the bitter truth. The youth unemployment as a proportion of total unemployment is 39 percent (CSO, 2014, p. 33). Table 5 demonstrates that poverty is correlated with underemployment and unemployment. The underemployment and unemployment rates for the head of household are 41.6 and 39.4 percent respectively. In addition, $38.2 \%$ of the heads of households are inactive and are not able to engage in any type of work. Thus, the poverty rate is high when there are such incidents. 
Labour Market Characteristics (\%)

\begin{tabular}{|c|c|c|c|c|}
\hline Household Head Characteristics & Employed & Underemployed & Unemployed & Inactive \\
\hline Poverty Headcount & 35.0 & 41.6 & 39.4 & 38.2 \\
\hline Share of Poor Population & 66.6 & 17.3 & 5.0 & 11.2 \\
\hline Share of Total Population & 69.6 & 15.2 & 4.6 & 10.7 \\
\hline
\end{tabular}

Source: Data Adapted from CSO, 2014

Work and jobs for the population as a fundamental element of life are seen as a way to earn income, providing the possibility to meet the needs of the society. Labour shortages and rising unemployment spread economic, political, and social problems in society as well as bring physical and mental problems. As shown in table 6 , labour force participation for males is $80 \%$ at the national level, while for females is $18.5 \%$. The employment rate for males is higher compared with that of females. As a result, high unemployment rate caused families to earn less income, which do not cover all their daily expenses.

Table 6

Labour force indicators by sex and residence (\%)

\begin{tabular}{|c|c|c|c|c|c|c|c|c|}
\hline \multirow[b]{2}{*}{ Sex and Residence } & \multicolumn{2}{|c|}{ Urban } & \multicolumn{2}{|c|}{ Rural } & \multicolumn{2}{|c|}{ Kuchi } & \multicolumn{2}{|c|}{ National } \\
\hline & $\frac{0}{\sum^{\pi}}$ & $\begin{array}{l}\frac{0}{\mathbb{Z}} \\
\underset{0}{0} \\
\text { II }\end{array}$ & $\frac{\stackrel{0}{J}}{\Sigma}$ & 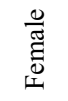 & $\frac{\frac{0}{\pi}}{\Sigma}$ & 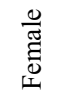 & $\frac{0}{\sum^{\pi}}$ & $\underset{\substack{\mathbb{0} \\
\mathbb{I}}}{\stackrel{0}{\mathbb{Z}}}$ \\
\hline Labour force participation & 72.0 & 12.9 & 82.1 & 19.3 & 91.4 & 36.6 & 80.0 & 18.5 \\
\hline Employment rate & 66.5 & 10.8 & 77.1 & 15.9 & 87.2 & 33.9 & 74.9 & 15.5 \\
\hline Under employment rate & 7.7 & 14.1 & 17.5 & 24.0 & 20.8 & 29.8 & 15.4 & 22.8 \\
\hline Unemployment rate & 7.7 & 16.7 & 6.1 & 17.6 & 4.7 & 7.2 & 6.4 & 16.5 \\
\hline
\end{tabular}

Source: Data Adapted from CSO, 2014

\subsubsection{Economic Dependence}

Economic dependence is the most obvious consequence of poverty. It is also the most important factor in terms of backwardness and political affiliation. Individual and a society that has suffered from economic dependence progressively lose its status over time in the prevalence of disorders that arise in the personal and social environment. Poor communities often have valuable raw materials but due to lack of capital are not able to produce industrial goods. As a result, they often have no choice except to export low priced raw materials to industrialized countries and then import the higher priced manufactured products. Therefore, exporting raw materials and importing goods in some developing countries are relevant to economic dependence. 


\subsubsection{Absence or Lack of Investment}

Absence or lack of investment is also an indicator of poverty. This phenomenon causes the inefficient use of the resources across the country. Therefore, the economic sectors such as agriculture, industry, and services are not improved in order to solve the challenges and problems that communities faced.

\subsubsection{Lack of Strategic Planning}

One of the major causes of poverty in Afghanistan has been lack of strategic planning of governments, or lack of accurate and comprehensive strategy to reduce poverty across the country. Past governments have not been formulating programs or important steps to eradicate poverty that has raised difficulties to the current Government of Afghanistan. The lack of a detailed plan for a prosperous rural economy that makes up about $70 \%$ of the total population can be recognized as a major cause of poverty.

\subsubsection{Drought and Natural Disasters}

Afghanistan is a country with a high-risk profile, due to a combination of climatic and natural circumstances and being a historically grown hotbed of social and political conflict and economic vulnerability (CSO, 2014, p. 105). Countries like Afghanistan are unprepared to deal with natural disasters. Floods, plant diseases, droughts and locust infestations can lead to food shortages and poverty.

\subsubsection{Lack of Population Control}

The lack of population control within the family is another factor of poverty in Afghanistan. Large number of children in families in which there is no chance for education, health, food and other requirements can take down most of the families in poverty. Poorer households have more dependents. In many cases, one or two family members are working and earn less income, therefore, the income per capita in terms of household size is too low and does not cover the daily expenses. According to the Ministry of Economic (2010) "The number of family members in a household can put pressure on food and other resources, therefore significantly pushing the household toward poverty. The overall average household size in Afghanistan is 7.3 persons. Poorer households are larger with an average size of 8 , while non-poor households have an average 6.9 members."

\subsubsection{Income Generation Sources}

Agriculture and livestock activities are the main source of income generation for families in most parts of the country. The majority of family members are engaged in agriculture and livestock. In most rural areas, agricultural products are mainly for home consumption. Any surplus is too little to bring to market and thus families often cannot earn enough to pay for education and healthcare. Therefore, agriculture and livestock in terms of low productivity are critical to poverty reduction and economic development. Table 7 shows the main income sources for households in rural and urban areas. The main source of income for households in urban area is non agricultural activities such as wage non-farm (44.3\%); trade, craft and transport (36.6\%). On the contrary, the main source of income generation for households in rural areas is farming (44.3\%) with more than $50 \%$ of their own consumption. Overall, at the national level the main income sources are farming and wage non-farm (36.2\% and $29.9 \%$ respectively). 
Income generation sources (\%)

\begin{tabular}{|l|c|c|c|}
\hline \multicolumn{1}{|c|}{ Income source } & Rural & Urban & National \\
\hline Farming & 44.3 & 2.8 & 36.2 \\
Home consumption & 23.8 & 1.3 & 19.4 \\
Market & 20.5 & 1.5 & 16.8 \\
\hline Wage farm & 7.0 & 0.5 & 5.7 \\
\hline Wage Non-farm & 26.3 & 44.3 & 29.9 \\
\hline Trade, Craft and Transport & 12.0 & 36.6 & 16.9 \\
\hline Other & 3.4 & 10.2 & 4.7 \\
\hline Total & $\mathbf{1 0 0}$ & $\mathbf{1 0 0}$ & $\mathbf{1 0 0}$ \\
\hline
\end{tabular}

Source: 2007/08 NRVA cited in (MoE, 2010).

\subsubsection{Disability}

Households headed by disabled persons are considered poorer to other families. Due to a long time of war across the country, a lot of people have lost part of their body which has made them disabled. In this regard, the disabled people are almost the poorest in many communities. Most disabled people are males, who were traditionally obligated to work outside of the house and females remain as housewives. Therefore, many disabled are not able to work and earn income thus the family members suffer from poverty.

\subsubsection{Access to Basic Services}

Public services and facilities are very low in the rural areas of Afghanistan. Access to basic services such as health, clean water, electricity, and sanitation is also related to poverty and the overall well-being of people in Afghanistan. The lack of effective government has caused the collapse of health services in the country and it has left a great impact on human capital. In the past, due to a lack of medical facilities, the mortality rate of mothers and children were very high. Overall the health condition is very serious across the country, but the rural communities suffer more. Health centres, hospitals, and doctors that can deliver prevention services are not enough and lack of essential medicines and medications are other major factors that have made the health situation worse. Mostly the rural communities are not able to invest in the health care of their children in order to decrease the mortality rate.

Mostly, the poor families do not have access to the basic services across the country. Lack of access to these public services is another critical issue for poor people, which lead them to suffer from poverty and remain poor for a long time. As shown in table 8 , less than one quarter $(23 \%)$ of poor families have access to safe drinking water, around one-quarter have access to electricity, and only $2 \%$ of them have access to sanitation. Access to safe drinking water, electricity, and sanitation for non-poor families is $(29 \%, 45 \%$, and $7 \%$ respectively). 
Access to Basic Services (\%)

\begin{tabular}{|l|c|c|c|}
\hline \multicolumn{1}{|c|}{ Services } & Safe Water & Electricity & Sanitation \\
\hline Poor & 23 & 33 & 2 \\
\hline Non-Poor & 29 & 45 & 7 \\
\hline Total & $\mathbf{2 7}$ & $\mathbf{4 1}$ & $\mathbf{5}$ \\
\hline
\end{tabular}

Source: NRVA 2007/08 cited in (MoE, 2010).

In many rural areas, the poor spend more time collecting water for drinking and daily use. Drinking water resources including lakes and streams are located far from some residential areas. In this regard, some family members must walk hundreds of meters to water sources and spend significant time collecting water. Access to health services is a multi-dimensional concept. It not only relates to the physical distance to health facilities or the travel time involved, but also involves the cost of travel and services, as well as opportunity costs, cultural responsiveness to clients' needs, mobility of women, and even the 'value' attached to the health and survival of specific household members, such as children and women (CSO, 2014, p. 83).

\subsection{Political Instability and External Intervention}

Afghanistan, because of its strategic location, has been a victim of external intervention throughout modern history. The British Empire and Czarist Russia made several failed attempts to dominate and control it. The British imperial government was keen to make Afghanistan the 'buffer state' between British India and Czarist Russia. The British fought three Afghan wars - two in the 19th century and one in 1917 - but each time it met with failure and disappointment (Baral, 2013, p. 701). Afghanistan is a place where foreign troops come into the country from other continents to portray their ascendency. Therefore, in the second decade of the $21^{\text {st }}$ century and the fourth wave of security dialogue based on military security, political, economic, social, environmental, and cultural flows, Afghanistan's problems cannot be studied by a traditional security perspective. Afghanistan has been at war for 30 years.

But there is a contradiction regarding the role of international actors in Afghanistan for bringing peace and security, or insecurity and crisis. Afghanistan is now the centre of controversy in other countries. The military strategy in Afghanistan lost its use. Military cooperation in terms of fighting against al Qaeda and the Taliban had positive achievements in the country. In the past 10 years, democratization also had positive achievements in the country. That is why the strategy of economic cooperation solves the problems of the country. Human and financial statistics of the last ten years show that when regional and international cooperation in Afghanistan is realized, spending is reduced. In 2004, a total of 60 people were killed by NATO in Afghanistan. This figure rose in 2010 to more than 700 people. America has been spending over $\$ 2$ billion a week in the Afghanistan war (Centre for Strategic Research, 2011). This demonstrates that the only solution in Afghanistan is one of regional and international cooperation.

\subsection{Political Competition of Afghanistan's Neighbours}

South Asia: One important issue which caused the continuing crisis in Afghanistan is that the country is located in South Asia. Mainly competition between India and Pakistan has negatively impacted on the stability and the security of Afghanistan. These two countries (India and Pakistan) have been competing with 
each other on the basis of religion and geography for a long time. India is interested in acting as a regional and international power, but faces security problems with Pakistan.

Both India and Pakistan are aware that what happens in Afghanistan will have a significant impact on their long-drawn adversarial relationship. Each of them appears to think that a government of its choice in Kabul would tilt the balance of power in the subcontinent in its favour. India may gain sufficient leverage over Pakistan by defeating the latter's design and move in Afghanistan (Baral, 2013, p. 711). In fact, the India-Pakistan competition has merged them together and reflects their relations with countries outside the region, such as those with China, Iran, USA, and Afghanistan. In recent years, the USA has begun to play in this particular game. The USA tries to be close to Pakistan. Washington plays the game through competition with China and India, as well. China tries to be close to Pakistan in order to compete with India. In fact, the relationship between India and Pakistan with countries outside the region is based on the competition between the two countries. Pakistan's relationship with Afghanistan is based on two reasons: first, it prevents Pashtun independence; second the prevention of Afghanistan developing a close relationship with India. India has also pursued its interests through its relationship with Afghanistan: to show its strength internationally, that there is a regional power, and to observe the behaviour and actions of Pakistan.

Central Asia: Central Asian countries have a common geography, cultural heritage, and security issues. The problem the Central Asian countries have is the most threatening to the stability of their own security. Threats such as terrorism, weak institutions, identity crises, economic problems, and others have internal as well as external causal factors. For example, Central Asian narcotics' trafficking is a threat to regional security.

Countries with common security also compete on many issues such as water. Another issue is boundaries. There is a competition on terrorism. For example, the Islamic Party of Uzbekistan, which causes tension in the region, works in Afghanistan. The Central Asian security complex has three categories of actors. Kazakhstan and Uzbekistan are stronger countries in terms of economics, politics, and security. Two countries, Tajikistan and Kyrgyzstan, are the poorest countries in the region. Turkmenistan is placed between the two groups. Competition in this region is between stronger countries and countries outside the region of Central Asia which play a role based on their competition. There is less cooperation between Afghanistan and Central Asia. Central Asia tries to prevent the entrance of drugs and terrorism in the region, therefore is keeps away from Afghanistan. In addition, Russia and China are trying to play leading roles in the region.

The Persian Gulf: The third security complex is the Persian Gulf region. Competition between Iran and Saudi Arabia is also another challenge for Afghanistan. Moreover, the USA with the support of Saudi Arabia is trying to reach its political goal through Afghanistan.

During the Soviet occupation in Afghanistan, Saudi Arabia was the only country that, based on religion and wealth, had a strong opposition against the influences of the Soviet Union. With a communist coup in Afghanistan and the Soviet occupation, Saudi activities were expanded more than before. Saudi Arabia entered Pakistan to fight against communism. Saudi Islamic organizations have tried to build mosques and religious schools in Pakistan, especially the border region of Pakistan where Pashtun communities lived. Afghan youths, who during war did not have schools, were attracted to the religious schools in Afghanistan and Pakistan, therefore the influence of Saudi Arabia increased in these countries, resulting in most of the Taliban leaders having studied for several years in Saudi Arabia and trained in Pakistan or Saudi Arabia.

\section{DISCUSSION}

The above mentioned indicators show that the level of poverty in Afghanistan is very high. These indicators are interrelated with each other and negatively impact the well-being of the overall community, push- 
ing it to live in poverty. First, conflict generated insecurity, with numerous adverse effects on the poor. The collapse of the state and rule of law resulted in local power-holders taking control in regions and localities, often with no check on their authority. An estimated 5.9 million Afghans left the country and one million Internally Displaced Persons (IDPs) were displaced within Afghanistan, making one in every three Afghans a refugee or an IDP. Second, the conflict destroyed physical capital, including the small-scale traditional infrastructure which the rural poor relied on for livelihoods as well as personal assets. Third, the lack of an effective state led to the collapse of public service delivery and took a heavy toll on human capital. Under the Taliban administrative, school attendance was low and girls were almost completely barred from attending schools. Infant and under-five mortality, as well as maternal mortality, were estimated to be among the highest in the world, and malnutrition affected about 50 percent of children under age five. "The average life expectancy was little more than 40 years, similar to the pre-conflict level (World Bank, 2005, p. 16)".

As Afghanistan faces many challenges and a high percentage of the populations live under the poverty line, how can poverty be reduced in Afghanistan? Since many factors caused Afghanistan to remain as a poor country and a large number of populations suffer from extreme poverty, it is not easy to answer this question. But there are many prospective solutions, such as regional economic integration and peace building across the country. In an integrated development approach, issues of basic service provision and interventions aiming to balance the vagaries of informal labour markets in Afghan cities need to go along with efforts to support the poor in extending, strengthening and diversifying their social assets (Schutte, 2009, p. 483). I argue that integrating Afghanistan into a regional framework with its neighbouring countries will change the situation for all the countries in the region, as well as for the international community. Integration and regional cooperation provide security for all the countries in the region. For example, controlling the borders will prevent the transferring of terrorism. Provision of security will encourage all sectors in furthering their activities and lead the rural communities to be busy with their agriculture and livestock activities. Soon Afghanistan will experience the transfer of security control from international to Afghan security forces. In this regards, integration and regional cooperation will be an important opportunity for Afghanistan to increase the level of security in the region.

Kozyulin pointed out that: "The Americans believe that Afghanistan's economic problems can be resolved by making the country part of the regional transit and communication networks. But that will require cooperation from neighbouring countries and, insofar as possible, the participation of private investors. Small and medium foreign businesses (including American companies) have already realized the possibilities of cashing in on war, and built some infrastructure on both sides of the Afghan border." (2013, p.73). With the assistance of its neighbors and through the creation of a peaceful environment, Afghanistan can overcome its historical isolation and take its rightful place in the "Heart of Asia". For example, development of the transportation sector in Afghanistan is a key to facilitate the trade within the region. Therefore, the creation of the "New Silk Road" will benefit Afghanistan by bringing together Eurasia and South Asia via new road, rail and energy corridors. As a whole, neighbouring countries will also benefit from such assistance. For example, Kazakhstan, as the largest landlocked country in the world, will have the possibility to access the global market, and South Asia in particular.

In recent years with the increasing crisis in Afghanistan, most experts and even some foreign countries including the United States of America (USA) and France have emphasized the region's role in resolving the Afghan crisis (Centre for Strategic Research, 2011). Additionally, the Centre for Strategic Research (2011) pointed out that many regional and Western analysts realized that the main reason for the lack of control over the situation in Afghanistan by foreign forces was the region's lack of understanding and lack of cooperation with nations neighbouring Afghanistan. Though there is a consensus on the necessity of regional co- 
operation regarding the Afghanistan crisis, and despite America's policy to integrate the issues of Afghanistan and Pakistan, so far, no regional or international action has been taken in this regard.

Within the contexts and challenges in international cooperation, influential actors in Afghanistan can be divided into two categories. The main triangle of influential actors in Afghanistan consists of Iran, Pakistan, and USA. Actors such as Russia, China, India, Saudi Arabia and the Central Asian states are actors who have their own interests in the Afghan issue, but this does not affect the significance of the impacts of the original actors. These actors usually force their influence with the help of other actors in Afghanistan. Saudi Arabia, United Arab Emirates (UAE), and China play a role in Afghanistan through Pakistan. European countries follow the Afghan issue through USA. Cooperation between influential regional actors is the key to peace and stability in Afghanistan. But the main problem is that the goals and interests of these three actors are not aligned.

In general, the security dynamics between India and Pakistan; between Central Asia and Russia; and between Iran and Saudi Arabia does not allow for a regional solution for Afghanistan. The solution is to accept the security dynamics, but the players must not use Afghanistan for achieving their goals. A solution can be drawn through economic cooperation programs.

Finally, I argue that regional integration and economic cooperation change the situation in all neighbouring countries. The important part of integration and regional cooperation is the stabilization of Afghanistan. Working together to find political solutions for the Afghan people is essential. The problems of Afghanistan cannot be solved magically, and it must be acceptable that only Afghans can decide the country's way forward. It is better that the social and economic rehabilitation of Afghanistan be of their own efforts, not relying on the international community. Integration and regional cooperation for the improvement of important sectors such as agriculture, education, and infrastructure would have possible impacts on lives of the people of Afghanistan. About 70-80\% of Afghanistan's population lives in rural areas. Security and stabilization will encourage Afghans back into their productive activities on the land, which have important economic impacts. In general, by having a secure society, there would be many positive changes, including improved agriculture sector, successful small business enterprises and access to the internal and external markets. As a result, economic cooperation between Afghanistan and its neighbours as well as far away countries would be a key alternative to reduce poverty across the country.

\section{CONCLUSION}

Continuous war, security problem and political instability are the important key indicators of poverty in Afghanistan. War, for example, in its turn forced people to immigrate, suffer from unemployment and disability. Since the past governments have been involved in war for a long time, there was less attention on providing basic services, such as health, education, and many other public goods and services. Moreover, there is less cooperation between Afghanistan and its neighbors in the region. Lack of regional integration and cooperation forced Afghanistan to be a conflict battle for many countries.

According to the common and conflicting goals and motivations of the influential actors in Afghanistan for Regional Cooperation and the interests of the partnership, the challenges of security in neighbouring Afghanistan are the main obstacles in the development of regional cooperation to solve the crisis in Afghanistan. Despite several initiatives for economic integration, the Afghanistan problem remains a major challenge for actors. Among the three main actors in Afghanistan (USA, Pakistan, and Iran), the goals and benefits of Iran and the USA require stability and security in Afghanistan. Both countries pay a lot of expenses for the crisis in Afghanistan. But Pakistan is in conflict with the goals and interests of peace and 
stability in Afghanistan. Indeed, the main obstacle is that out of these goals, the common goals cannot be extracted, while there are competitions. The USA is concerned with the formation of regional cooperation; Iran finds more active role in Afghanistan. Iran is also concerned about the continued presence of the USA in Afghanistan, and consolidating its position in the area of cooperation.

Regional economic and political cooperation would be important alternatives to solving the security problem and reduce poverty in Afghanistan. Insecurity in Afghanistan may affect the security of neighbouring countries and force them to be involved in solving such big problems for a long time.

\section{REFERENCES}

Agola, Nathaniel O., \& Awange, Joseph L. (2014). Globalized Poverty and Environment: 21st Century Challenges and Innovative Solutions. New York: Springer

Baral, J.K. (2013) The Afghan Game: Interests and Moves, Strategic Analysis, 37:6, 700-715, DOI: $10.1080 / 09700161.2013 .847038$

Central Statistics Organization. (2014). National Risk and Vulnerability Assessment 2011-12. Afghanistan Living Conditions Survey. Kabul: CSO.

Centre for Strategic Research. (2011). The Need for Regional Cooperation on the Afghan Crisis: Challenges and Benefits of this Cooperation. Retrieved from http://www.csr.ir/departments.aspx?abtid=01\&depid=44\&semid=470.

Kozyulin, Vadim. (2013) Afghanistan-2014 and the Taliban with its head held proud but low, Security Index: A Russian Journal on International Security, 19:1, 73-76, DOI: 10.1080/19934270.2013.759731.

Ministry of Economy. (2010). Poverty Status in Afghanistan: A Profile based on National Risk and Vulnerability Assessment (NRVA) 2007/2008. Washington, D.C.: The World Bank

Purves, Ruth. (2008). Afghanistan without Poverty: A Plain Language Guide to Poverty in Afghanistan. Kabul: USAID

Schütte, Stefan Dr. (2009). Informal (In)security in Urban Afghanistan, Iranian Studies, 42:3, 465-491, DOI: $10.1080 / 00210860902907404$

The World Bank. (2005). Afghanistan - State Building, Sustaining Growth, and Reducing Poverty. Washington, D.C.: The World Bank 